\title{
Karakterisasi Faktor Sosial Ekonomi Berdasarkan Analisis Komponen Principal pada Pertanian Periurban Kota Surabaya
}

\author{
Dwi Iriyani ${ }^{1}$ dan Pangesti Nugrahani ${ }^{2}$ \\ ${ }^{1}$ FMIPA-UT dpk UPBJJ-UT Surabaya \\ ${ }^{2}$ Fakultas Pertanian UPN "Veteran" Jawa Timur \\ 1dwiiriyani@ut.ac.id, ²pangesti_nug@yahoo.com
}

\begin{abstract}
ABSTRAK
Pertanian di sekitar wilayah perkotaan ("periurban agriculture") mempunyai prospek ekonomis yang tinggi dan dapat dipacu menjadi tipe usahatani komersial. Usahatani yang demikian sangat cocok dikembangkan bagi masyarakat sekitar perkotaan yang pemilikan lahan umumnya sempit. Adanya pertanian di sekitar wilayah perkotaan, berarti akan mendekatkan produsen dengan konsumen, sehingga dapat mengurangi kerusakan produk dan biaya transportasi. Pengembangan pertanian periurban perlu dilengkapi dengan data sosial ekonomi usahatani dan karakteristik petani, dalam mengembangkan usahatani ke dalam bentuk agribisnis. Produktivitas dan kualitas sumber daya manusia, dalam hal ini petani pada pertanian periurban, merupakan indikator dari komponen faktor sosial yang menjadi ciri karakter kawasan periurban. Sedangkan indikator komponen faktor ekonomi meliputi pertumbuhan ekonomi dan struktur ekonomi. Ada beberapa teknis analisis faktor, satu diantaranya adalah menggunakan metode analisis komponen utama (Principal Component Analysis). Metode ini merupakan cara untuk mengekstraksi variabel asli, di mana terbentuknya faktor-faktor atau variabel laten baru adalah bersifat acak, yang selanjutnya dapat diinterpretasi sesuai dengan faktor atau komponen atau konstruk yang terbentuk. Penelitian ini bertujuan untuk mengidentifikasi karakter petani dan faktor-faktor yang menjadi latar belakang (konteks sosial ekonomi) serta pertimbangan petani untuk menekuni dan mengembangkan pertanian periurban.
\end{abstract}

Kata Kunci: : Data sosial ekonomi usaha tani, karakteristik petani periurban, dan analisis faktor. 


\section{PENDAHULUAN}

Kota Surabaya merupakan kota besar kedua setelah Jakarta. Tahun demi tahun perkembangan Kota Surabaya semakin pesat. Ciri khas kota besar identik dengan pembangunan gedung-gedung yang menjulang tinggi dan semakin berkurangnya lahan untuk bercocok tanam. Adanya kecenderungan perubahan pola pemanfaatan lahan dari agraris ke non agraris akan mempengaruhi perilaku bertani dari para petani di pinggiran kota (periurban).

Kenyataan menunjukkan bahwa sampai saat ini alih fungsi lahan subur ke non pertanian masih berlangsung, bahkan seolah terjadi legitimasi perkembangan dan penyimpangan penggunaan lahan yang terjadi di lapangan. Di sisi lain perhatian para pejabat pemerintah kota terhadap pertanian masih relatif kecil. Para penduduk di perkotaan pun belum banyak menyadari arti pentingnya pertanian urban dan peri urban sebagai pencipta hubungan timbal balik yang harmonis antara manusia dan alam sekitarnya (Woodsworth, 2001).

Adanya kecenderungan perubahan pola pemanfaatan lahan dari agraris ke non agraris akan mempengaruhi perilaku bertani dari para petani di pinggiran kota. Ada kemungkinan motivasi dan semangat bertani dari sebagian petani di daerah pinggiran kota akan mengendor ketika mereka melihat adanya alternatif lain untuk memperoleh sumber pendapatan selain dari bekerja di sektor pertanian. Tidak menutup kemungkinan mereka akan menjual lahan pertaniannya, apalagi bila terdesak oleh kebutuhan dana besar untuk menyekolahkan anaknya, memperbaiki rumah dan sebagainya. Di sisi lain masih banyak petani yang mencoba tetap bertahan bekerja di sektor pertanian dengan alasan yang beragam.

Sayuran sebagai salah satu komoditas hortikultura, memiliki potensi untuk dikembangkan pada areal pertanian kota dan pinggiran kota (urban and periurban agriculture). Salah satu aspek mutu produk sayuran adalah tingkat kontaminasi yang disebabkan oleh kontaminan mikroba, logam berat, dan residu pestisida.

Penelitian Iriyani dkk. (2014) menunjukkan bahwa tidak terdeteksi residu pestisida pada tiga jenis sayuran yang diproduski pertanian periurban di kota Surabaya, yaitu Bayam, Sawi dan Kangkung. Hasil analisis terhadap kandungan logam $\mathrm{Pb}$ pada ketiga jenis sayuran tersebut menunjukkan angka yang masih jauh dari batas minimum yang disyaratkan berdasarkan SNI (Standar Nasional Indonesia). Penelitian sebelumnya terhadap beberapa spesies tanaman sayuran daun yang dibudidayakan pada pertanian periurban di Kota Surabaya, menunjukkan kandungan klorofil, karotenoid, dan vitamin C yang tidak berbeda nyata dengan tanaman sayuran berlabel organik (Iriyani, 2013). Dengan demikian besar peluang untuk pengembangan produksi pertanian khususnya komoditi sayuran di areal pertanian periurban di Kota Surabaya.

Pengembangan pertanian periurban perlu dilengkapi dengan data sosial ekonomi usahatani dan karakteristik petani, dalam mengembangkan usahatani ke dalam bentuk agribisnis. Karakteristik petani, kondisi lingkungan, lahan marjinal dan sempit pada lahan pertanian periurban, dapat menjadi dasar dalam menentukan arah pengembangan pertanian periurban. 
Produktivitas dan kualitas sumber daya manusia, dalam hal ini petani pada pertanian periurban, merupakan indikator dari komponen faktor sosial yang menjadi ciri karakter kawasan periurban. Sedangkan indikator komponen faktor ekonomi meliputi pertumbuhan ekonomi dan struktur ekonomi (Desrainy dkk., 2010).

Selain itu, ada faktor sosial ekonomi dan pertimbangan manfaat non market yang menentukan keputusan petani untuk tetap bertahan atau meninggalkan usahataninya. Faktor sosial ekonomi yang diamati mempengaruhi keputusan petani menjual lahan terkait dengan tingkat pendidikan dan peranan pertanian dalam kehidupan rumah tangga petani. Terdapat kecenderungan yang nyata bahwa semakin tinggi tingkat pendidikan anggota rumah tangga usia kerja maka semakin besar peluang rumah tangga petani yang bersangkutan untuk menjual lahan. Di sisi lain, peluangnya menjadi semakin kecil jika pertanian dapat diandalkan sebagai sumber lapangan kerja dan sumber pendapatan rumah tangganya (Sumaryanto, 2010)

Penelitian Husodo (2005) terhadap sikap petani di kawasan periurban Kota Yogyakarta, terungkap bahwa sebagian petani di kawasan periurban, usahatani merupakan pekerjaan utama namun bagi sebagian yang lain merupakan pekerjaan sambilan, bahkan ada yang menjadikan usahatani sebagai hobi. Namun ada pula yang bersikap perlu menjaga lahan periurban untuk generasi yang akan datang, karena usaha tani periurban ini dapat menghasilkan tambahan pendapatan, mendukung ketahanan pangan keluarga, dan memperbaiki kualitas lingkungan.
Kota Surabaya sebagai kota
metropolis tentu mengandung
konsekuensi bagi penataan dan
perluasan wilayah perkotaan. Para
petani mengalami apa yang disebut
proses pemutusan ikatan tradisi
(Setyobudi, 2001). Petani dipaksa
memasuki ruang perkotaan yang
membutuhkan tingkat adaptasi yang
berbeda dengan wilayah ekologis
sebelumnya, yaitu pedesaan. Bagi
petani yang masih bertahan untuk
tetap bekerja di sektor pertanian di
pinggiran kota, perilaku kehidupan
rumah tangga petani sangat
dipengaruhi oleh dinamika
perubahan stukural yang
berangang dataran tersebut. berlangsung di daearah tersebut. Dengan asumsi bahwa setiap rumahtangga petani berupaya memaksimalkan utilitasnya, maka petani akan mengalokasikan sumberdaya yang dimiliki untuk mendapatkan keuntungan yang maksimal. Dengan demikian, perubahan struktur perekonomian di daerah periurban akan disikapi dengan cara memanfaatkan perubahan tersebut guna memperoleh tambahan pendapatan bagi rumahtangganya.

Sikap dan pandangan terhadap usahatani periurban ini tidak terlepas dari latar belakang dan karakteristik petani. Karakterisitik tersebut antara lain meliputi usia, tingkat pendidikan, tanggungan keluarga, serta pengalaman dalam bertani (Siregar, 1999).

Menurut Husodo (2005), luas lahan, status lahan dan kepemilikan lahan, juga merupakan faktor yang mempengaruhi WTL (Willingness to Leave) terhadap pertanian periurban. Dalam rangka mengoptimalkan sumberdaya alam yang dikuasai petani di wilayah sekitar perkotaan, banyak masalah yang timbul akibat dari: 1) kepemilikan lahan yang relatif 
sempit, 2) lahan usahatani umumnya bukan milik petani (sewa ataupun bagi hasil), 3) keterbatasan modal, serta 4) pengetahuan petani, khususnya penerapan teknologi untuk meningkatkan produktivitas lahan masih kurang (Ginting, 2010).

\section{METODE PENELITIAN}

Analisis faktor merupakan salah satu metode statistik yang dapat dipergunakan untuk menemukan hubungan antar sejumlah variabel yang bebas satu sama lain, sehingga dapat dibuat satu atau beberapa kumpulan variabel saja (Santoso, 2002). Analisis faktor mencoba menemukan hubungan antar sejumlah variabelvariabel yang saling bebas satu sama lain sehingga dapat dibuat satu atau beberapa set variabel yang lebih sedikit dari jumlah variabel awal. Dalam hal ini variabel yang memiliki korelasi terbesar akan berkelompok membentuk suatu set variabel (membentuk faktor).

Analisis faktor akan memudahkan intrepretasi hasil penelitian karena telah mengurangi jumlah variabel hingga menjadi lebih sedikit, memilih faktor yang dapat menjelaskan keterkaitan antar variabel asli, menyederhanakan deskripsi dari satu set data yang besar, serta memudahkan menganalisis suatu fenomena dengan data yang sangat besar.

Ada beberapa teknis analisis faktor, satu diantaranya adalah menggunakan metode analisis komponen utama (Principal Component Analysis). Metode ini merupakan cara untuk mengekstraksi variabel asli, di mana terbentuknya faktor-faktor atau variabel laten baru adalah bersifat acak, yang selanjutnya dapat diinterprestasi sesuai dengan faktor atau komponen atau konstruk yang terbentuk.

Metode yang digunakan dalam penelitian ini adalah metode deskriptif dengan pendekatan kuantitatif dan teknik studi kasus di empat wilayah pertanian periurban di Kota Surabaya. Sampel yang diambil adalah petani yang melakukan kegiatan pertanian sayuran pada lahan pertanian periurban Kota Surabaya. Teknik pengambilan sampel menggunakan purposive sampling (Sugiyono, 2012). Jumlah sampel yang diambil sebanyak 68 sampel.

\section{Responden}

Jumlah sampel/responden ditentukan sebanyak 68 orang, dengan komposisi 17 orang sampel petani di wilayah Surabaya Barat, dan 17 orang sampel petani di wilayah Surabaya Timur, 17 orang wilayah Surabaya Selatan dan 17 orang di wilayah Surabaya Utara. Teknik pemilihan sampel adalah sampel random sederhana (Sample Random Sampling) yang merupakan salah satu sampel probabilitas dimana setiap individu memiliki peluang yang sama untuk dipilih. metode ini digunakan ketika populasi diperkirakan tidak memiliki karakteristik khusus yang dapat mempengaruhi keterwakilan sampel atas populasi (Nasir, 2003). Artinya dalam pengambilan populasi tidak memperhatikan strata dan diperkirakan bahwa populasi bersifat homogen.

\section{Analisis Data}




Analisis deskripsi dilakukan sebagai langkah pertama sebelum analisis statistik inferensial, yang berupa peringkasan, pengklasifikasian dan penyajian data. Sedangkan analisis inferensial dilakukan dengan analisis faktor (Factor Analysis) dengan bantuan software SPSS 16.0.

Faktor unik berkorelasi satu dengan yang lain dan dengan common factor. Common factor dapat dinyatakan sebagai kombinasi linier dari variabel yang diteliti.

Model analisis faktor dinyatakan dengan formula sebagai berikut :

$$
\begin{aligned}
& \mathrm{Fi}=\mathrm{Wi1X} 1+\mathrm{Wi} 2 \mathrm{X} 2+\mathrm{Wi} 3 \mathrm{X} 3 \\
& +\ldots \ldots \ldots \ldots \ldots+\text { WikXk } \\
& \text { dimana : Fi = Factor ke-i } \\
& \text { yang diestimasi } \\
& \mathrm{Wi}=\text { Bobot atau koefisien }
\end{aligned}
$$

Variabel sebagai faktor yang diukur pada penelitian ini adalah :

$$
\begin{aligned}
& \mathrm{X} 1=\text { Usia (Tahun) } \\
& \mathrm{X} 2=\text { Tingkat Pendidikan } \\
& \mathrm{X} 3 \text { = Jumlah Tanggungan } \\
& \text { Keluarga (Orang) } \\
& \mathrm{X} 4=\text { Jumlah Jenis Komoditi } \\
& \mathrm{X} 5=\text { Kemudahan } \\
& \text { Memperoleh Modal } \\
& \mathrm{X} 6=\text { Luas lahan }(\mathrm{Ha}) \\
& \mathrm{X} 7 \text { = Pengalaman Bertani } \\
& \text { (Tahun) } \\
& \mathrm{X} 8=\text { Pendapatan yang } \\
& \text { diperoleh (Rp) } \\
& \mathrm{X} 9=\text { Jumlah tenaga kerja } \\
& \text { dibayar (Orang) }
\end{aligned}
$$

$$
\begin{aligned}
& \mathrm{X} 10=\text { Asal Tempat Tinggal } \\
& \text { (Warga Sby \& Non Sby) } \\
& \mathrm{X} 11=\text { Lokasi lahan (Jarak } \\
& \text { 100-500 m) } \\
& \mathrm{X} 12 \text { = Kemudahan } \\
& \text { Memperoleh Saprodi } \\
& \mathrm{X} 13=\text { Kemudahan } \\
& \text { Pemasaran Hasil } \\
& \mathrm{X} 14=\text { Konsistensi Sikap } \\
& \text { Berusahatani } \\
& \mathrm{X} 15 \text { = Tipe lahan yang } \\
& \text { dikerjakan (Sawah } \\
& \text { Tadah Hujan \& Irigasi) } \\
& \text { X16 = Status Kepemilikan } \\
& \text { Lahan } \\
& \mathrm{X} 17=\text { Keberlanjutan } \\
& \text { Usahatani }
\end{aligned}
$$

\section{Uji Validitas dan Reliabilitas}

Sebelum kuesioner diberikan pada para petani periurban maka dilakukan uji coba penelitian agar informasi yang diperoleh lebih akurat dan obyektif. Untuk uji coba penelitian ini, kuesioner yang telah kami rancang disebarkan kepada 20 orang petani kemudian dilakukan uji validitas dan realiabilitas, yaitu untuk mengevaluasi item-item atau pertanyaan-pertanyaan yang mengukur konstrak/faktor penelitian dalam suatu kuesioner.

Dalam penelitian ini validitas yang digunakan adalah validitas konstrak yang merupakan tipe validitas untuk mempertanyakan apakah konstrak atau karakteristik dapat diukur secara akurat oleh indikator-indikatornya. Validitas konstrak diukur dengan koefisien korelasi antara skor masing-masing indikator/item pertanyaan (Xj) dengan skor totalnya/faktor (X). Koefisien validitas diukur dari korelasi 
Pearson (Malhotra, NK dan Birks, D.F., 2007).

Reliabilitas adalah suatu tingkatan yang mengukur konsistensi hasil jika dilakukan pengukuran berulang pada suatu karakteristik. Pengujian reliabilitas dapat dihitung dengan menggunakan formula Cronbach's alpha (Urbina, S.; 2004).

\section{HASIL DAN PEMBAHASAN}

\section{Keragaan (Performance) Sosial Ekonomi Petani Peri Urban}

Semakin

pesatnya perkembangan Kota Surabaya sebagai inti Surabaya Metropolitan Area (SMA), turut serta dalam menciptakan profil petani peri urban. Hal ini diindikasikan dengan semakin banyaknya masyarakat yang mencoba mengais rezeki dengan tetap mempertahankan ketergantungan di sektor pertanian. Para petani secara tidak langsung dipaksa memasuki ruang perkotaan yang membutuhkan tingkat adaptasi yang berbeda dengan wilayah ekologis sebelumnya, dalam hal ini ruang pedesaan atau desa.

Bagi petani yang masih bertahan untuk tetap bekerja di sektor pertanian di pinggiran kota, perilaku kehidupan rumahtangga mereka sangat dipengaruhi oleh dinamika perubahan struktural yang berlangsung di daerah tersebut. Diasumsikan bahwa setiap rumahtangga petani berupaya memaksimalkan utilitasnya, maka mereka akan mengalokasikan sumberdaya yang dimiliki untuk mendapatkan keuntungan yang maksimal. Dengan demikian, perubahan struktur perekonomian di daerah pinggiran kota akan dibaca dan disikapi dengan cara memanfaatkan perubahan tersebut guna memperoleh tambahan pendapatan bagi rumahtangganya. Sehingga perlu diketahui bagaimana karakteristik baik ditinjau secara sosial dan ekonomi keberadaan petani peri urban ini sebagai penentu eksistensinya di Kota Surabaya.

\section{Asal Tempat Tinggal}

Sebuah tempat tinggal biasanya berwujud bangunan rumah, tempat berteduh, atau struktur lainnya yang digunakan sebagai tempat manusia tinggal. Dalam konteks tertentu tempat tinggal memiliki arti yang sama dengan rumah, kediaman, akomodasi, perumahan, dan arti-arti yang lain. Unit sosial yang tinggal di sebuah tempat tinggal disebut sebagai rumah tangga. Umumnya, rumah tangga adalah sebuah keluarga, walaupun rumah tangga dapat berupa kelompok sosial lainnya, seperti orang tunggal, atau sekelompok individu yang tidak berhubungan keluarga. Kelompok masyarakat agraris dan industrial terdiri dari rumah tangga-rumah tangga yang tinggal di tempat tinggal yang bermacam-macam jenisnya, tergantung jenis pekerjaannya atau dalam hal ini bertani. Adapun karakteristik petani berdasar asal tempat tinggal dapat dilihat pada gambar sebagai berikut :

Gambar 1. di bawah dapat diidentifikasi profil petani periurban Kota Surabaya yang dikorelasikan dengan status domisili sesuai dengan Kartu Tanda Penduduk, maka di ketahui yaitu sebanyak 39 orang petani berasal dari Kota Surabaya dan sisanya sebanyak 11 orang yang berdomisili diluar Kota Surabaya. Mayoritas petani yang berasal dari Kota Surabaya diakui memang memiliki kemudahan dalam menjalankan usahataninya dibandingkan petani daerah lain. Seperti halnya tidak habis dalam 


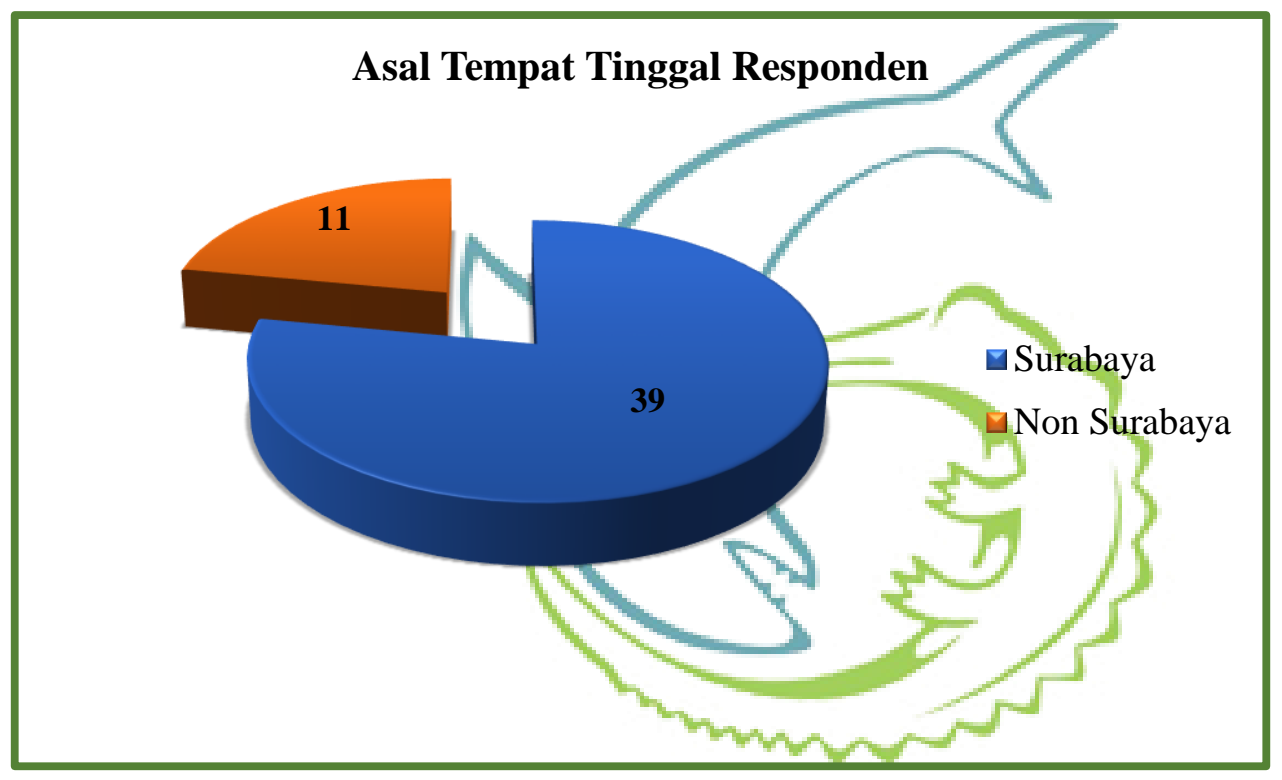

\section{Gambar 1. Karakteristik Responden Berdasar Asal Tempat Tinggal}

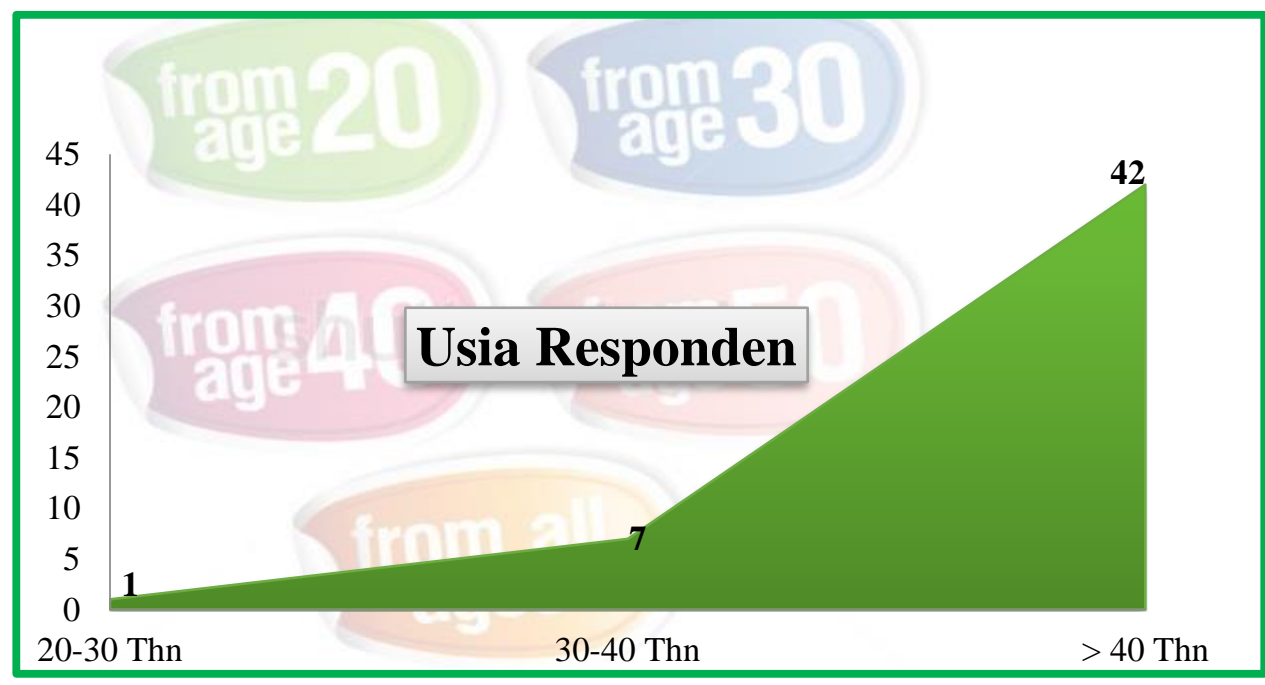

Gambar 2. Karakteristik Responden Berdasar Usia

biaya transportasi, lebih mengenal wilayah bahkan telah terbentuk sosialisasi dengan masyarkat sekitar areal pertanian.

\section{Usia}

Usia petani menunjukkan kondisi produktif atau tidaknya tenaga kerja yang terdapat di suatu dareah. Tenaga kerja produktif berada pada usia 25 hingga 40 tahun, sedangkan jika kurang atau lebih dari usia tersebut akan tergolong sebagai tenaga kerja kurang produktif tetapi masih termasuk dalam usia kerja. Adapun karakteristik petani berdasar usia dapat dilihat pada gambar 2 .

Berdasarkan hasil penelitian yang ditampilkan pada Gambar 2. dapat diketahui bahwa petani peri urban Kota Surabaya mayoritas usia lebih dari 40 tahun yaitu berjumlah 42 
orang berada pada usia kerja. Petani yang terlibat dalam usahatani periurban, mempunyai usia yang berbeda-beda terdapat 1 orang berada pada usia 20 sampai dengan 30 tahun, dan terdapat tujuh orang berada pada usia antara 30 sampai dengan 40 tahun. Hal ini menunjukan bahwa petani berada pada usia produktif lebih mendominasi dibandingkan petani yang non produktif, sehingga petani yang berada pada usia produktif lebih progresif terhadap inovasi baru sehingga cenderung lebih berani mengambil keputusan berusahatani. Di samping itu, masih besar potensi tenaga kerja yang dimiliki oleh petani tersebut dalam mengelola usahataninya, selanjutnya harapan untuk memperoleh pendapatan usahatani juga semakin besar.

\section{Jenis Kelamin}

Jenis kelamin sama artinya dengan seks di artikan sebagai perbedaan organ biologis antara laki-laki dan perempuan terutama pada bagian-bagian reproduksi serta kodrat Tuhan sehingga tidak dapat ditukar atau dirubah. Jenis kelamin merupakan kategori dalam masyarakat yang didasarkan pada seks atau jenis kelamin (perbedaan biologis). Perbedaan biologis dapat kita lihat dari struktur organ reproduksi, bentuk tubuh, suara, dan sebagainya. Atas dasar itu terdapat kelompok masyarakat laki-laki atau pria dan kelompok perempuan atau wanita. Jenis kelamin yang dimaksud dalam penelitian ini adalah jenis kelamin petani periurban pada saat dijumpai dan diberikan kuesioner. Adapun karakteristik petani berdasar jenis kelamin dapat dilihat pada gambar 3.

Berdasarkan hasil penelitian menunjukkan bahwa mayoritas profil petani periurban yang ada di Kota Surabaya adalah berjenis kelamin Laki-Laki yaitu sebanyak $94 \%$ dan sisanya sebanyak $6 \%$ adalah petani berjenis kelamin Perempuan.

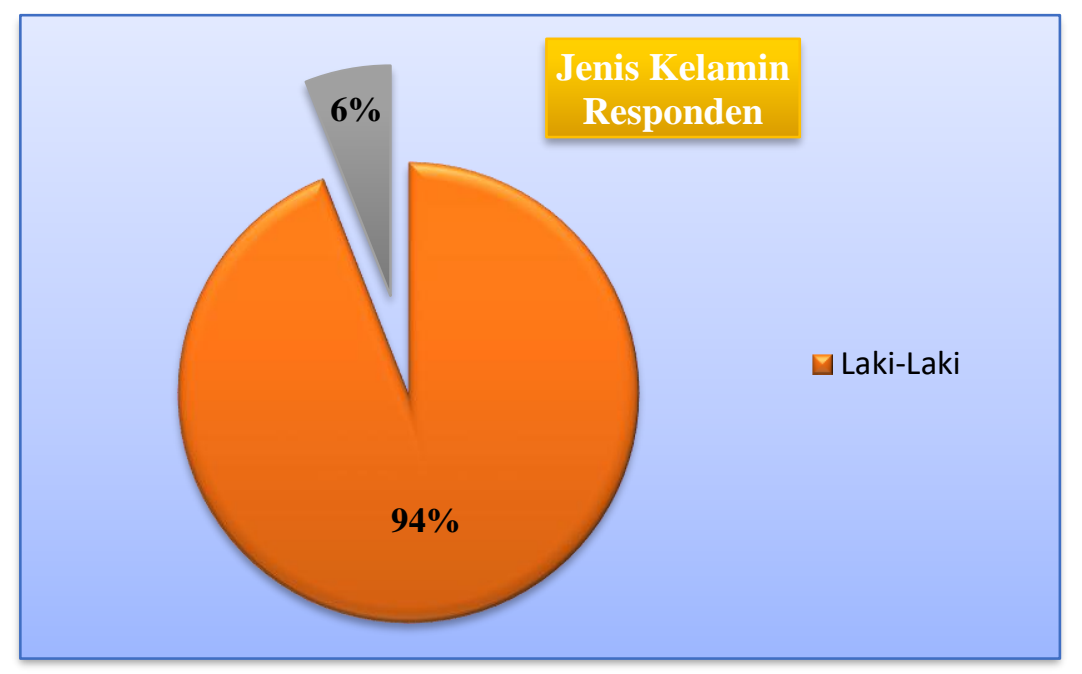

Gambar 3. Karakteristik Responden Berdasar Jenis Kelamin 


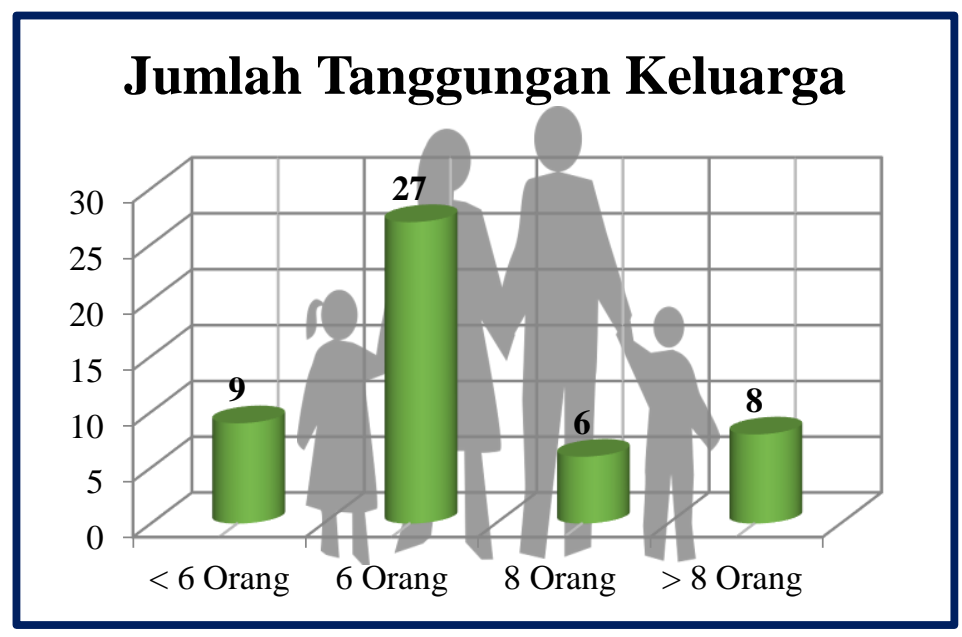

\section{Gambar 4. Karakteristik Responden Berdasar Jumlah Tanggungan Keluarga}

\section{Jumlah Tanggungan Keluarga}

Jumlah tanggungan keluarga yang dimaksud adalah banyaknya orang yang menjadi anggota dalam sebuah keluarga (rumah tangga). Satu keluarga merupakan suatu keluarga yang mempunyai nenek moyang sama, suatu keluarga yang disatukan, kekerabatan yang disatukan oleh darah atas perkawinan, pasangan perkawinan atau tanpa anak. Keluarga memiliki fungsi sebagai pengaturan seksual atau reproduksi, sosialisasi, afeksi, perlindungan dan fungsi ekonomi. Kebutuhan dasar yang dimaksud adalah makanan, pakaian, dan perumahan yang sering disebut dengan kebutuhan primer atau ekonomi. Manusia memiliki kebutuhan antara lain kebutuhan dasar (ekonomis) dan perumahan yang disebut dengan kebutuhan primer. Sehingga uang merupakan sarana untuk memenuhi kebutuhan dasar tersebut. Kalau kebutuhan dasar tidak terpenuhi, maka seseorang akan berkutat disekitar kebutuhannya saja. Sejalan dengan kebutuhan manusia seperti disebut diatas dapat dipahami bahwa semakin banyak anggota sebuah keluarga akan semakin besar pula kebutuhan yang akan dipenuhi. Dalam memenuhi kebutuhan tersebut tentu akan dibutuhkan adanya kerja keras agar memperoleh pendapatan yang besar guna memenuhi kebutuhan seluruh anggota keluarga. Adapun karakteristik petani berdasar jumlah tanggungan keluarga dapat dilihat pada gambar 4.

Berdasarkan hasil penelitian menunjukkan bahwa kebanyakan petani mempunyai tanggungan keluarga sebanyak 6 orang yaitu 27 petani responden menjawabnya, diikuti oleh tanggungan keluarga $<6$ orang yaitu 9 petani responden menjawabnya. Semakin banyak jumlah tanggungan keluarga maka semakin berat beban hidup yang dihadapi petani dan seharusnya diimbangi dengan semakin besar pendapatan yang diterima. 


\section{Pendidikan Akhir Responden}

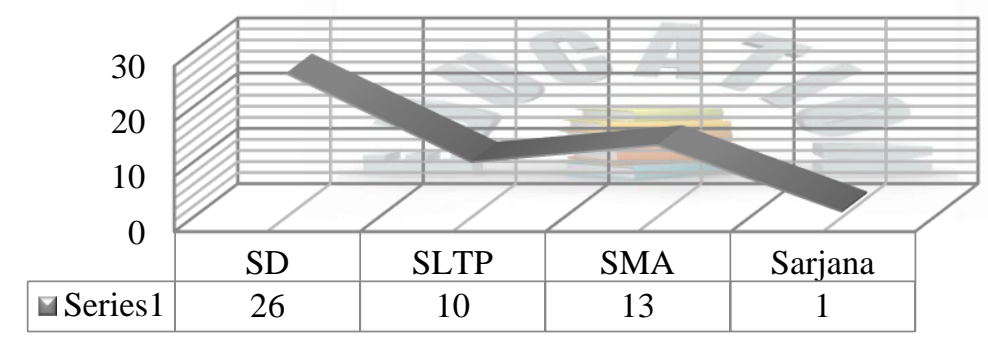

Gambar 5. Karakteristik Responden Berdasar Pendidikan

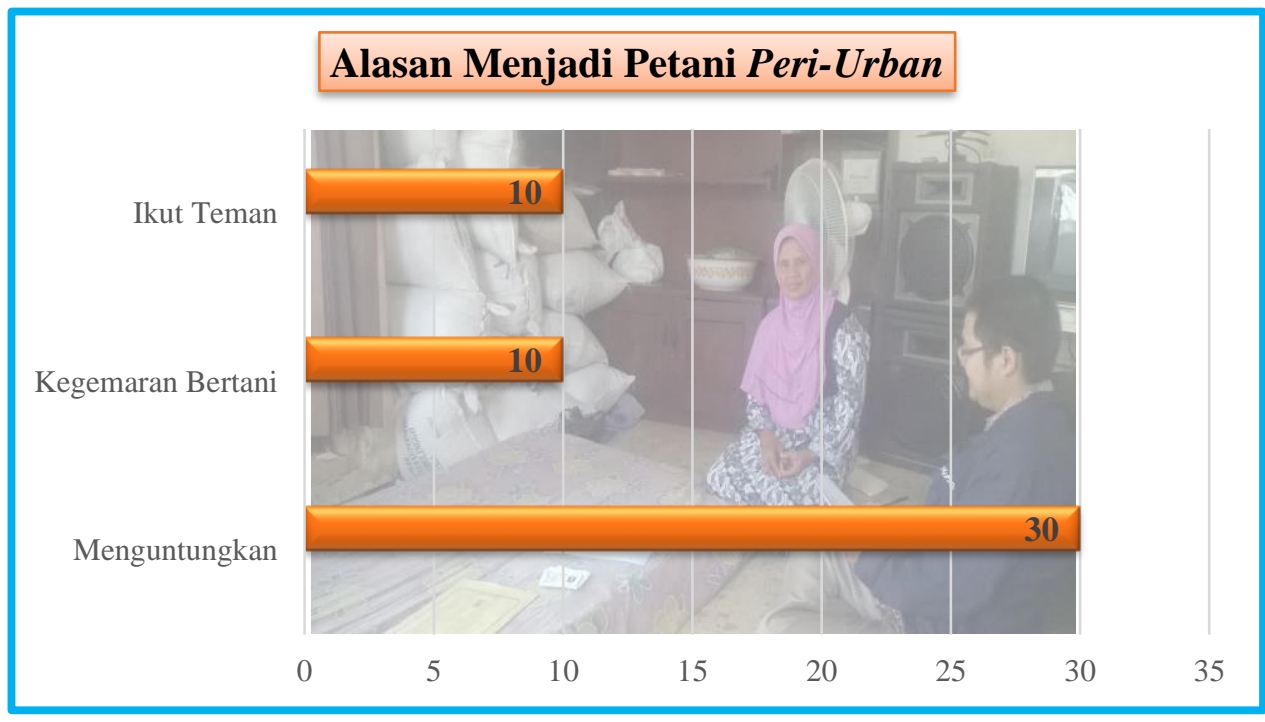

Gambar 6. Karakteristik Responden Berdasar Alasan menjadi Petani Periurban

\section{Pendidikan Terakhir}

Tingkat pendidikan dapat berpengaruh terhadap cepat lambatnya seorang petani menerima teknologi baru yang dapat menambah pengetahuan dalam rangka perubahan ekonomi atau usahataninya. Selain usia, pendidikan juga esensial dalam hal pengelolaan usaha tani.
Berdasarkan hasil penelitian seperti pada gambar 5 menunjukkan bahwa kebanyakan petani mencapai jenjang pendidikan hanya sebatas SD yaitu sebanyak 26 orang responden, diikuti oleh jenjang pendidikan SMA dan SLTP masingmasing yaitu sebanyak 13 dan 10 orang petani responden, sedangkan yang menarik petani responden 
bergelar sarjana hanya ditemukan sebanyak 1 orang petani responden.

\section{Alasan Menjadi Petani Peri-Urban Sebagaimana diketahui bahwa dampak majunya perkotaan berimplikasi pada meningkatnya pertanian Peri-Urban. Adapun karakteristik petani berdasar alasan menjadi petani periurban dapat dilihat pada gambar 6 . \\ Tampak pada gambar 6 . diatas bahwa alasan yang mendominasi masyarakat Surabaya untuk menjadi petani periurban adalah faktor keuntungan yang diterima yaitu sebanyak 30 orang petani sepakat menjawabnya, kemudian juga ditentukan oleh faktor kegemaran bertani dan ikut sesama petani.}

\section{Keikutsertaan dan Keaktifan Petani Peri-Urban dalam POKTAN}

Pembinaan usahatani melalui kelompok tani tidak lain adalah sebagai upaya percepatan sasaran. Petani yang banyak jumlahnya dan tersebar dengan pembinaan kelompok diharapkan timbulnya cakrawala dan wawasan kebersamaan memecahkan dan merubah citra usahatani sekarang menjadi usahatani masa depan yang cerah dan tetap tegar. Kelompok tani merupakan suatu bentuk perkumpulan petani yang berfungsi sebagai media yang diharapkan lebih terarah dalam perubahan aktivitas usahatani yang lebih baik lagi. Adapun karakteristik petani berdasar keikutsertaan dan keaktifan dalam kelompok tani dapat dilihat pada gambar 7 .

Tampak pada gambar 7 diatas bahwa sebagian besar (46 orang responden) menyatakan dirinya ikut serta dan aktif dalam aktivitas kelompok tani yang telah terbentuk dimana mereka melakukan kegiatan pertanian. Keaktifan dalam kelompok tani dapat dilihat dari tingkat kehadiran, keterlibatan dalam kegiatan dan diskusi dalam kelompok tani, tingkat keaktifan petani dalam kelompok tani diharapkan berhubungan positif dan berpengaruh nyata terhadap pendapatan yang diterima.

\section{Luas dan Tipe Lahan Petani Peri-} Urban

Luas lahan adalah merupakan luas areal persawahan yang akan ditanami padi pada musim tertentu. Pada umumnya lahan sawah merupakan lahan pertanian yang berpetak-petak dan dibatasi oleh pematang saluran untuk menahan/ menyalurkan air. Adanya luas lahan ini memudahkan dalam pengelompokan petani dan biasanya dibagi atas tiga macam yaitu luas lahan sempit, sedang dan luas, adapun karakteristik petani berdasar luas lahan dapat dilihat pada gambar 8.

Berdasarkan hasil analisis deskriptif menujukkan bahwa petani periurban Kota Surabaya cenderung memliki luas lahan sempit $(0,25-0,50$ ha). Padahal, lahan sebagai salah satu faktor produksi yang merupakan pabriknya hasil pertanian yang mempunyai kontribusi yang cukup besar terhadap usahatani. Besar kecilnya produksi dari usahatani antara lain dipengaruhi oleh luas sempitnya lahan yang digunakan. Namun, ada juga sisi positif petani yang memiliki luaslahan sempit diantaranya adalah upaya pengawasan saprodi semakin baik, tenaga kerja tercukupi dan alokasi modal pertanian tidak dalam skala besar sehingga resiko bisa diminimalisir.

Disisi lain, faktor fisik seperti kondisi lahan dan ketersediaan air menjadi faktor penentu tipe lahan. 


\section{Responden Ikut \& Aktif POKTAN}

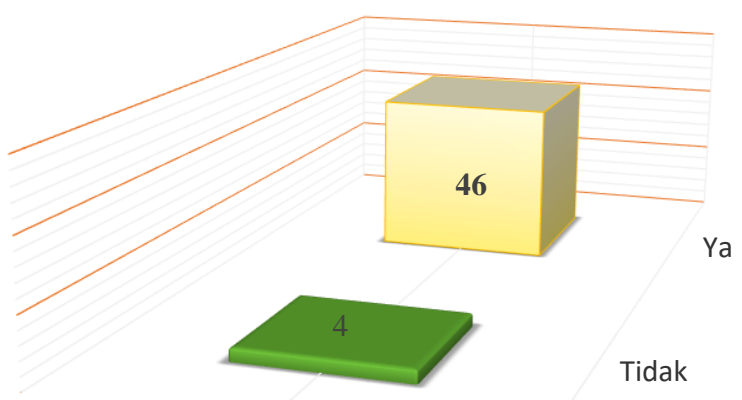

Gambar 7. Karakteristik Responden Berdasar Keikutsertaan dan Keaktifan Petani Peri-Urban dalam POKTAN

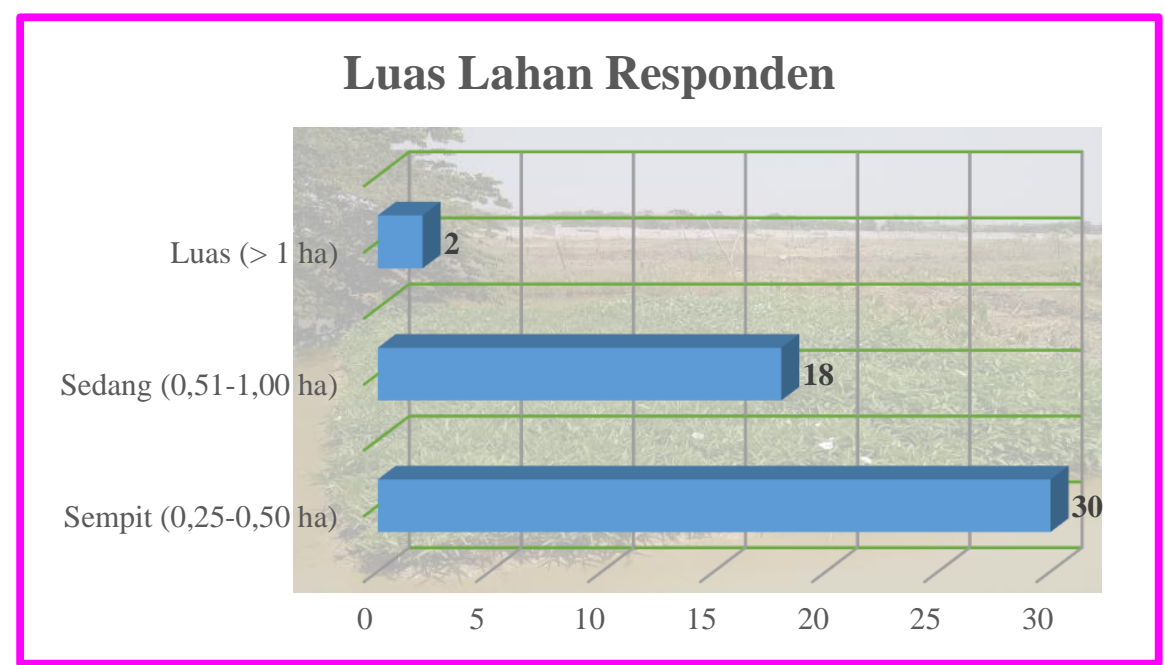

Gambar 8. Karakteristik Responden Berdasar Luas Lahan

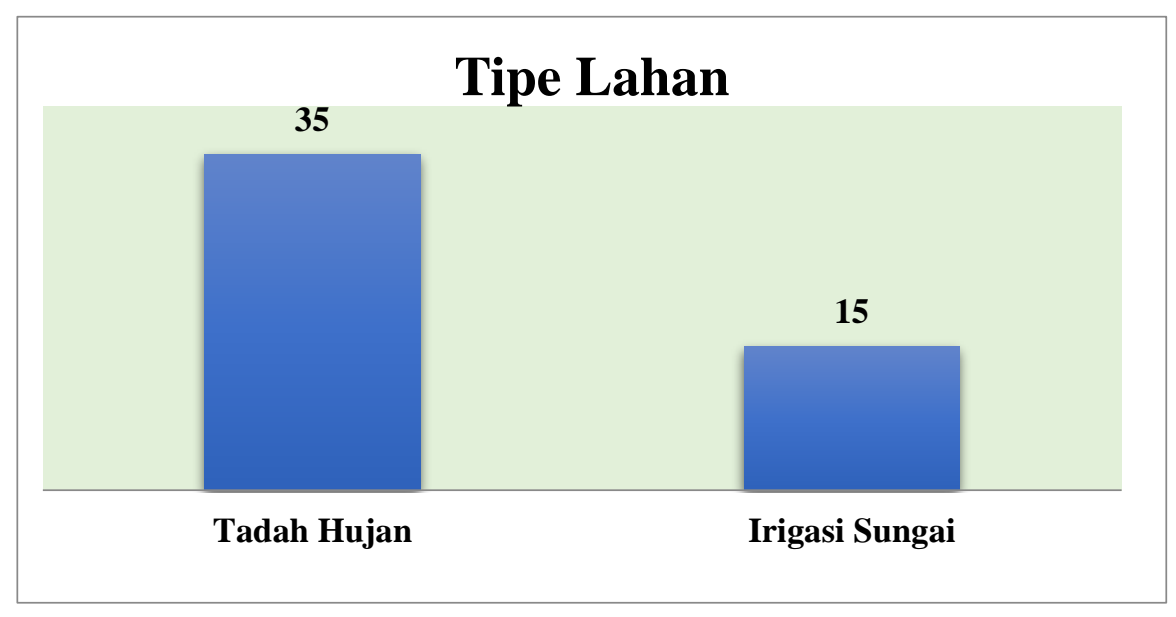

Gambar 9. Karakteristik Responden Berdasarkan Tipe Lahan 
Jenis Tanaman yang Dibudidayakan Responden

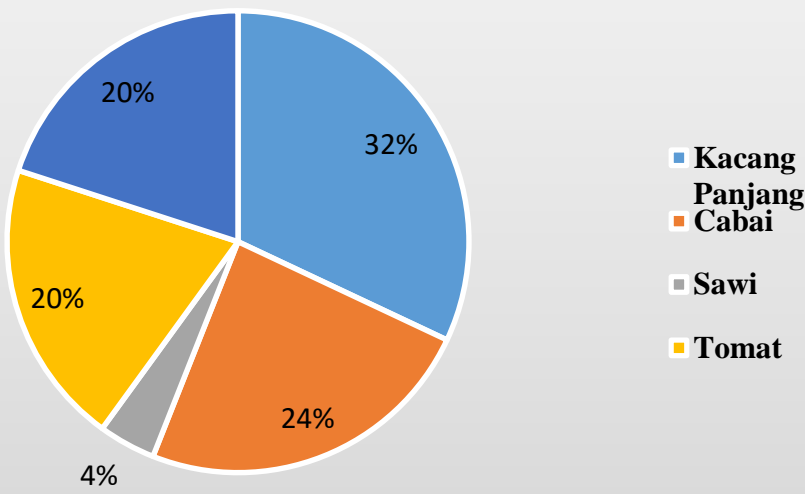

\section{Gambar 10. Karakteristik Responden Berdasar Jenis Tanaman yang di Budidayakan}

penelitian ini menemukan sebanyak 35 orang petani responden masih menggunakan sistem pengairan sawah tadah hujan, sedangkan 15 orang petani mengandalkan air dari sungai (Gambar 9).

\section{Jenis Tanaman yang \\ Dibudidayakan \\ Seorang petani sayur, pasti} banyak tahu tentang berbagai sayuran apa yang paling mudah dibudidayakan. Namun bagi sebagian orang yang baru saja ingin bertani, jenis tanah ini pasti akan menjadi hal yang asing, dan tentunya menarik untuk diketahui, oleh karena bercocok tanam itu gampanggampang susah. Susahnya itu terkadang ada pada tanaman yang sulit dibudidayakan, yang bisa dibilang membutuhkan keahlian ekstra untuk mengelolanya. Jenis tanaman yang dibudidayakan juga melalui proses pengalaman dengan mempertimbangkan hemat tenaga, waktu, dan biaya perawatan.

Berdasarkan hasil analisis deskriptif menunjukkan bahwa sebagian besar petani peri urban menanam Kacang Panjang 16 orang petani responden (32\%) dan terbanyak kedua adalah menanam Cabai yaitu sebanyak 12 orang (24\%) dan terendah diketahui menanam Sawi yaitu sebanyak 2 orang (4\%) dari keseluruhan petani sampel dalam penelitian ini.

\section{Tempat Jual Hasil Panen}

Penjualan hasil panan merupakan serangkaian proses distribusi hasil pertanian mulai dari petani sampai kepada konsumen. Proses pemasaran dan alur yang tepat akan berdampak pada keuntungan yang baik bagi petani, sehingga petani berhasil dalam usahataninya. Pada umumnya petani lebih suka menjual langsung hasil panennya kepada tengkulak karena lebih mudah (33 orang petani responden menjawabnya), mereka mendatangi petani pada saat panen, sehingga tidak perlu membawa ke pasar. Kelemahannya petani tidak dapat menentukan harga lebih dan untungnya minim, sedangkan 


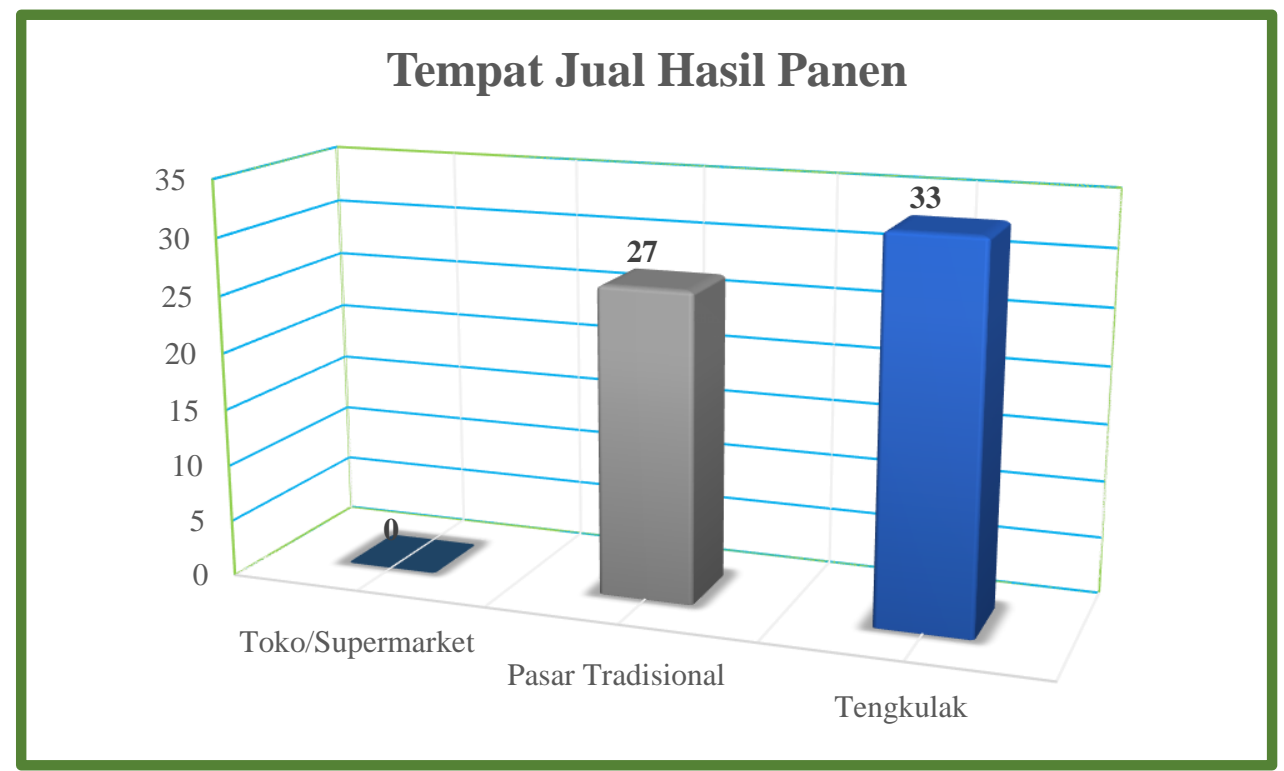

Gambar 11. Karakteristik Responden Berdasar Tempat Jual Hasil Panen

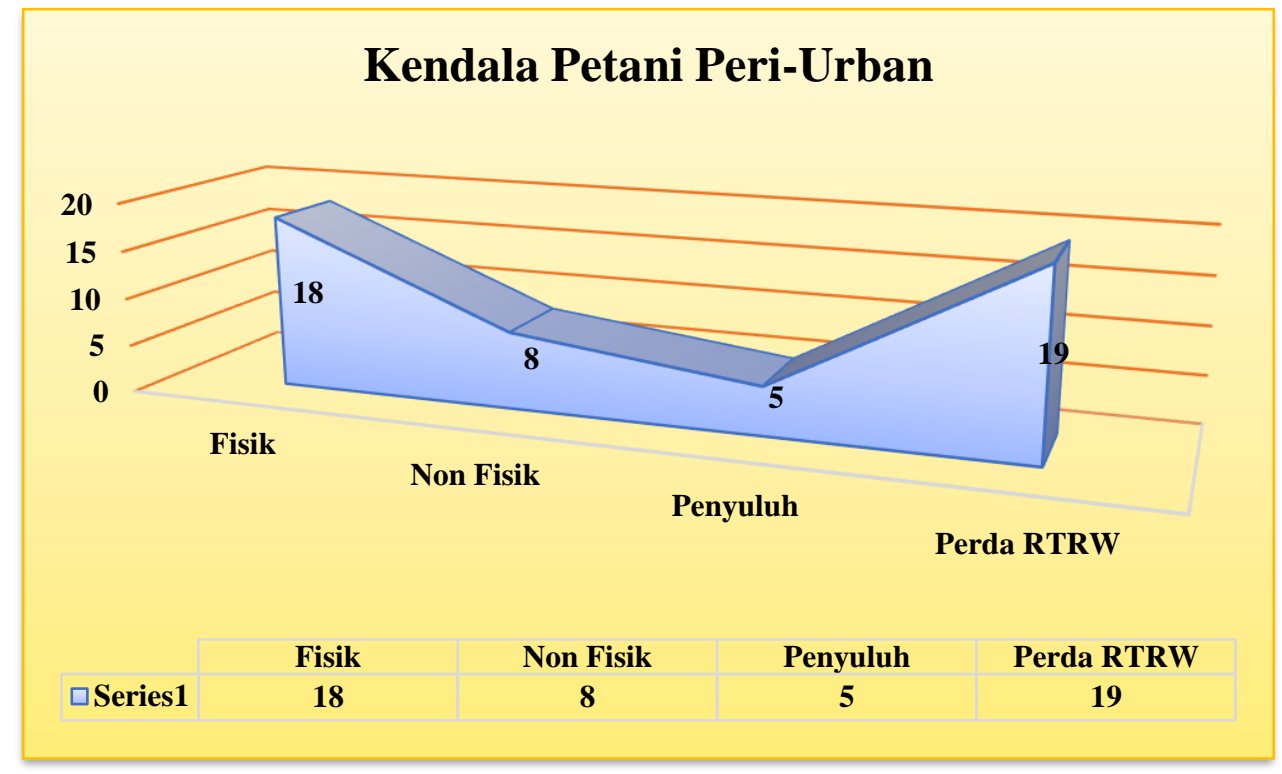

Gambar 12. Karakteristik Responden Berdasar Kendala yang Dihadapi

tengkulak dapat meraup keuntungan dari konsumen dan pengumpul dapat untung banyak karena dapat menjualnya kembali. Adapun karakteristik petani berdasar tempat menjual hasil panennya dapat dilihat pada gambar 11.
Kendala Petani Peri-Urban

Petani dikatakan sangat rentan terhadap usaha yang dilakukannya, baik itu bersifat fisik maupun non fisik. Ketahanan petani terhadap kendala-kendala tersebut pada akhirnya mampu menciptakan petani yang unggul. Faktor fisik lebih 


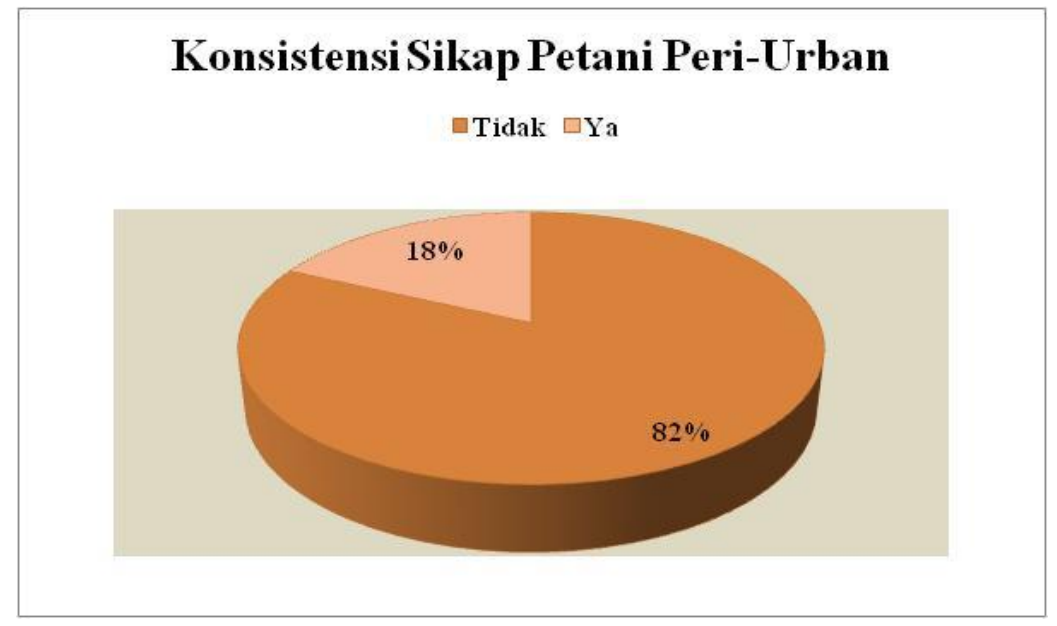

Gambar 13. Karakteristik Responden Berdasar Konsistensi Sikap

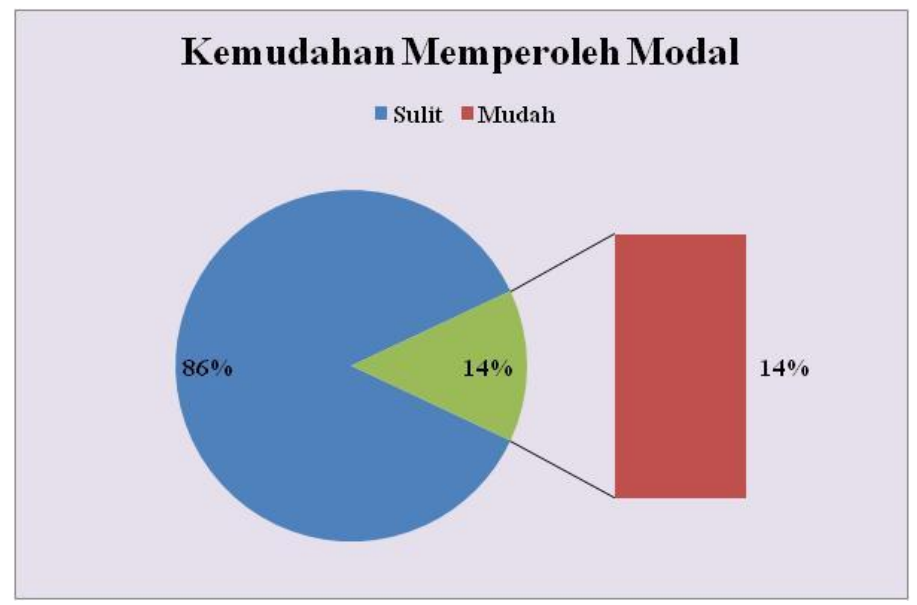

Gambar 14. Karakteristik Responden Berdasar Kemudahan

\section{Memperoleh Modal}

disebabkan oleh iklim, tanah, air dan kondisi lahan, sedangkan faktor non fisik seperti halnya modal, tenaga kerja, pemasaran, fasilitas kredit. Adapun karakteristik petani berdasar kendala yang dihadapi dapat dilihat pada gambar 12.

Berdasarkan hasil analisis deskriptif menujukkan bahwa petani peri urban menganggap kendala serius yang dihadapi adalah dari sisi perubahan Perda Rencana Tata Ruang Wilayah Kota Surabaya adalah sebanyak 19 orang petani yang menjawabnya. Hal ini mengindikasikan kegalauan diantara petani akan perubahan kebijakan yang seringkali menyudutkan mereka dalam konversi lahan untuk perumahan, industri bahkan ruko/kompleks perkantoran.
Keberlanjutan Usahatani Peri- Urban
Dari hasil penelitian, diketahui bahwa seluruh responden (100\%) Petani Peri-Urban Kota Surabaya mengatakan "ya" terhadap 
Tabel 1. Karakteristik Responden Berdasarkan Cara Memperoleh Bibit dan Saprodi

\begin{tabular}{c|cc}
\hline CARA MEMPEROLEH & BIBIT & $\begin{array}{c}\text { PUPUK DAN } \\
\text { PESTISIDA }\end{array}$ \\
\hline MEMBELI & & 50 \\
BANTUAN & 50 & 0 \\
LAINNYA & 0 & 0 \\
\hline
\end{tabular}

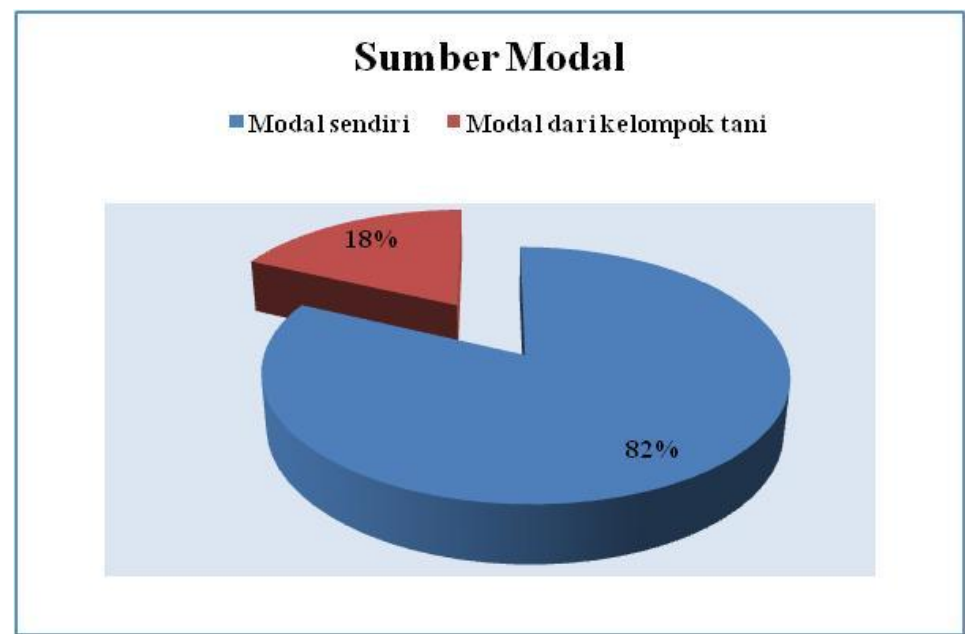

\section{Gambar 15. Karakteristik Responden Berdasar Sumber Modal}

keberlanjutan usahatani Peri-Urban. Pernyataan ini memiliki makna bahwa mereka yakin akan usahataninya dan masih akan melanjutkan usahataninya. Namun dari pernyataan sikap konsistensinya terhadap usahatani, hanya ada $18 \%$ petani yang bersikap konsisten seperti halnya pada gambar 13.

Keberlanjutan usaha tani digambarkan pada gambar 14 oleh petani tergantung dari faktor kemudahan memperoleh modal dan kemudahan memperoleh Saprodi. Untuk memperoleh modal usaha tani, sebanyak $86 \%$ responden menyatakan sulit, dan hanya $14 \%$ responden yang menyatakan mudah.

Modal usahatani yang selama ini mereka pergunakan, sebagian besar (82\%) merupakan modal sendiri. Sedangkan $18 \%$ responden lainnya berhasil memperoleh bantuan modal dari Kelompok Tani (Poktan) .

Selain faktor kemudahan untuk memperoleh modal usahatani, kemudahan untuk memperoleh sarana produksi pertanian (Saprodi), juga menjadi pertimbangan petani dalam melaksanakan kegiatan usahataninya. Sarana produksi pertanian yang dibutuhkan petani meliputi bibit atau benih tanaman, pupuk, dan pestisida (insektisida / fungisida). Pada penelitian ini diperoleh hasil bahwa seluruh $(100 \%)$ petani responden memperoleh sarana produksi pertanian yang berupa bibit, pupuk dan pestisida adalah dengan cara membeli (Tabel 1). 


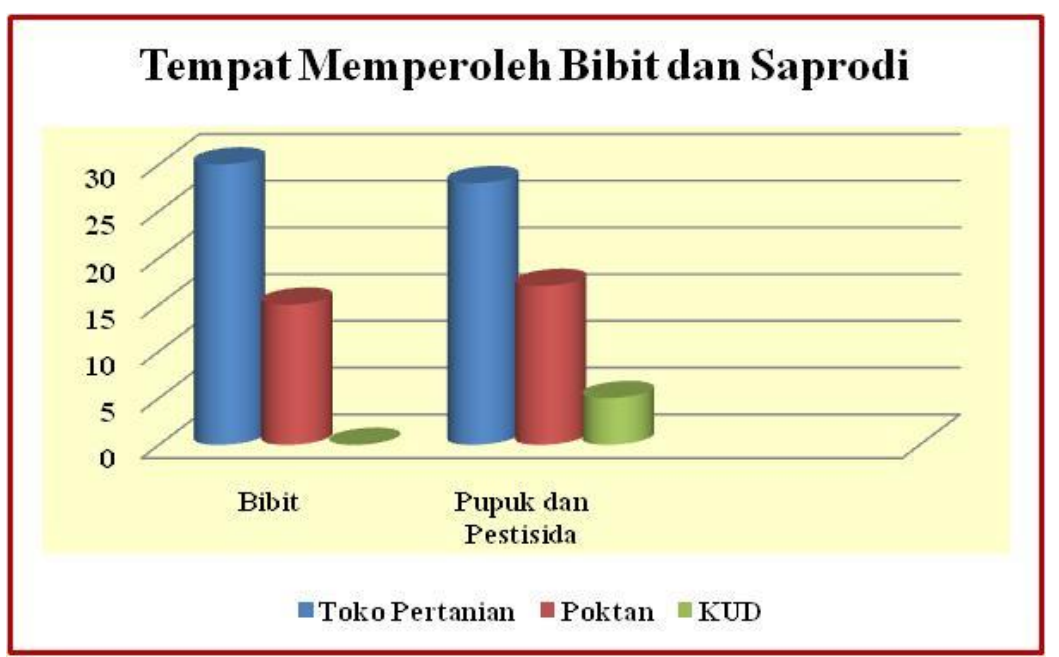

Gambar 16. Karakteristik Responden Berdasar Tempat Memperoleh Bibit dan Saprodi

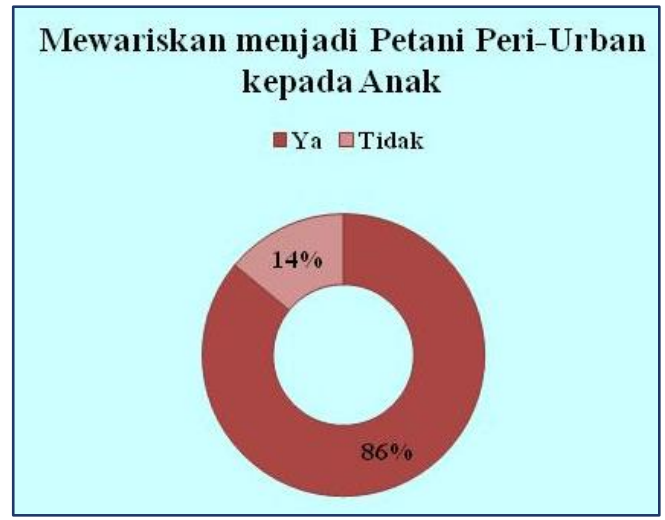

Gambar 17. Karakteristik Responden Berdasar Usaha Mewariskan menjadi Petani Peri-Urban kepada Anak

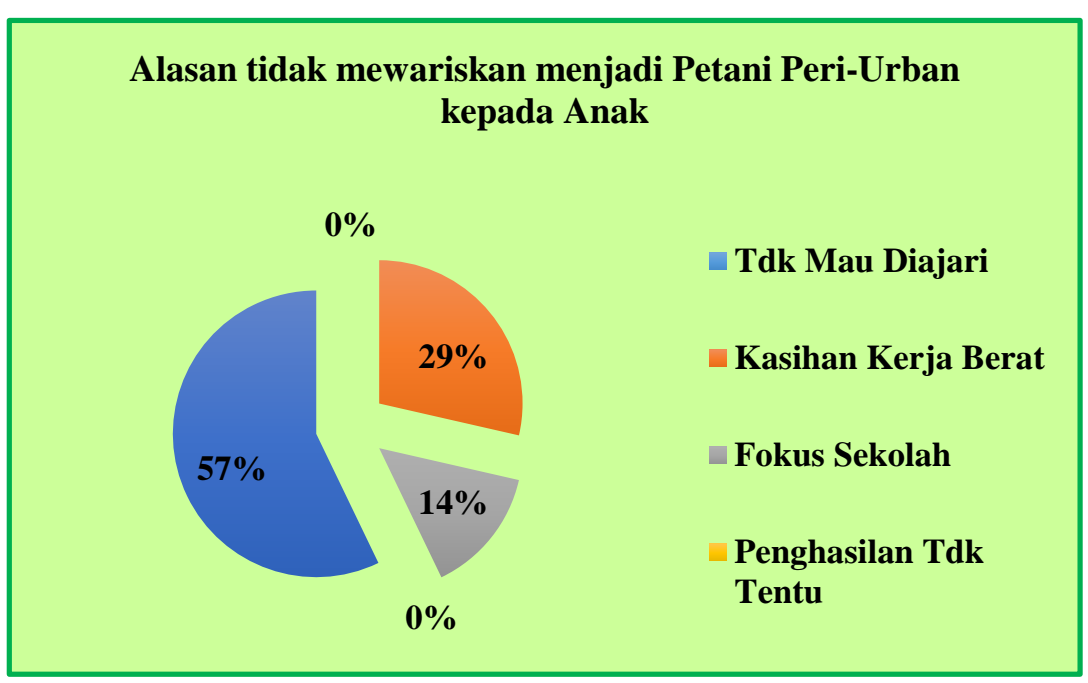

Gambar 18. Karakteristik Responden Berdasar Alasan Tidak Mewariskan menjadi Petani Peri-Urban kepada Anak 


\section{Persepsi terhadap penghasilan}

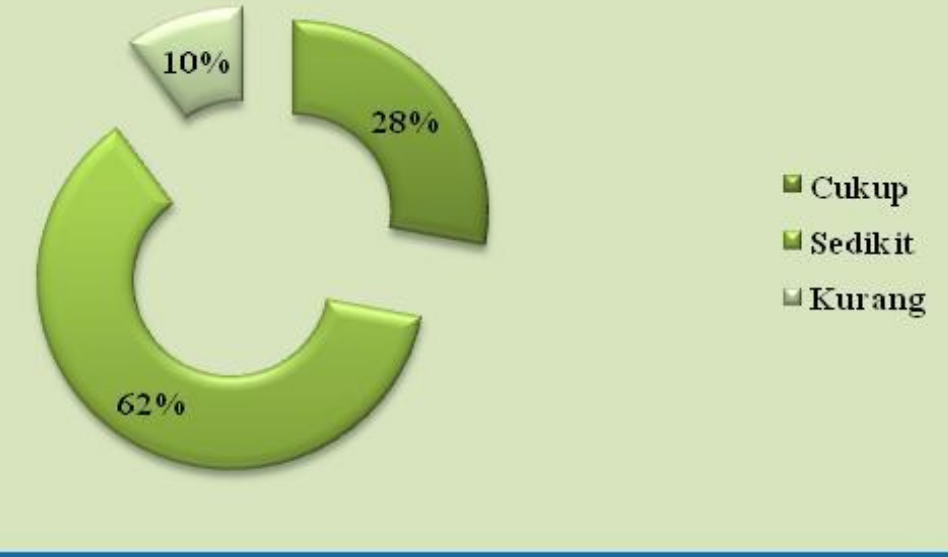

Gambar 19. Karakteristik Responden Berdasar Persepsi terhadap Penghasilan

Tabel 4. KMO and Bartlett's Test

Kaiser-Meyer-Olkin Measure of Sampling Adequacy.

Approx. Chi-Square $\quad 199,747$ 855

Bartlett's Test of Sphericity

Sig.

Sumber : Hasil Analisis Data (2015).

Mereka membeli bibit, pupuk dan pestisida dari Toko Pertanian, dari Kelompok Tani dan dari KUD. Sebanyak $30 \%$ responden membeli bibit atau benih, dan $28 \%$ responden membeli pupuk dan pestisida dari Toko Pertanian. Sedangkan responden yang membeli bibit dan pestisida dari Kelompok Tani, masing-masing sebanyak $15 \%$ dan $17 \%$.

Selain faktor teknis, keberlanjutan usatani para petani Peri-Urban ini juga dipengaruhi oleh faktor non teknis yaitu mewariskan usaha kepada anak. Sebanyak $86 \%$ responden menyatakan bahwa mereka berusaha mewariskan usahataninya kepada anak, sedangkan $14 \%$ lainnya tidak ingin mewariskan usahatani kepada anak. Mereka yang tidak ingin mewariskan usahatani kepada anak, memiliki pertimbangan tersendiri, antara lain: 1). anak tidak berminat atau tidak mau mempelajari cara usahatani orangtuanya, 2). orang tua merasa kasihan terhadap anaknya karena dianggapnya bahwa pekerjaan bertani terlalu berat bagi anak, 3). anak seharusnya hanya fokus kepada pendidikan atau kegiatan sekolahnya, 4). penghasilan dalam usahatani tidak tetap, dan 5). anak memperoleh lapangan kerja lain.

Dari hasil penelitian diketahui bahwa dari mereka yang tidak mewariskan usahatani kepada anak, sebanyak $57 \%$ responden menyatakan bahwa anaknya diharapkan akan memperoleh kesempatan bekerja bidang lain. Sebanyak 29\% responden merasa kasihan kepada anaknya bila 
anaknya menjadi petani. Sedangkan lainnya (14\%) menginginkan agar anaknya fokus untuk sekolah saja.

Salah satu faktor yang mempengaruhi keberlanjutan usahatani periurban adalah tingkat pendapatan petani. Pada penelitian ini, tingkat pendapatan petani tidak dapat dihitung secara kuantitatif, tetapi secara kualitatif berdasarkan persepsi masing-masing petani. Petani memaknai pendapatan yang mereka peroleh dari hasil usahatani, dapat digolongkan menjadi tiga yaitu: cukup, sedikit dan kurang.

Sebanyak $62 \%$ petani responden memaknai penghasilan dari usahatani ini cukup untuk makan dan biaya hidup sehari-hari. Selebihnya, sebesar $28 \%$ merasa bahwa penghasilan dari usahatani hanya sedikit, sedangkan sebanyak $10 \%$ merasa bahwa penghasilannya dari usahatani kurang mencukupi kebutuhannya.

\section{Identifikasi Faktor-Faktor Prinsipal dalam Kebijakan Pengembangan Pertanian Periurban Kota Surabaya \\ KMO measure of sampling adequacy merupakan indeks yang digunakan untuk menguji kesesuaian analisis faktor, nilainya minimal 0,5 . Hasil penelitian yang ditunjukkan seperti tabel 4.}

Tabel 5. Communalities

\begin{tabular}{lrr}
\hline \multicolumn{1}{c}{ Uraian } & Initial & Extraction \\
\hline Usia & 1,000 &, 589 \\
Tingkat Pendidikan & 1,000 &, 351 \\
Kemudahan Memperoleh Modal & 1,000 &, 288 \\
Pendapatan yang diperoleh & 1,000 &, 405 \\
Kemudahan Memperoleh Saprodi & 1,000 &, 451 \\
Kemudahan Pemasaran Hasil & 1,000 &, 631 \\
Keberlanjutan Usahatani & 1,000 &, 637 \\
Konsistensi Sikap Berusahatani & 1,000 &, 486 \\
Tipe lahan yang dikerjakan & 1,000 &, 797 \\
\hline
\end{tabular}

Sumber : Hasil Analisis Data (2015).

Tabel 6. Total Variance Explained

\begin{tabular}{cccccc}
\hline Component & \multicolumn{3}{c}{ Initial Eigenvalues } & \multicolumn{2}{c}{$\begin{array}{c}\text { Extraction Sums of } \\
\text { Squared Loadings } \\
\% \text { of } \\
\text { Total } \\
\text { Variance }\end{array}$} \\
\hline 1 & Total & $\begin{array}{c}\text { Cumulative } \\
\%\end{array}$ & of & & \\
2 & 4,634 & 51,492 & 51,492 & 4,634 & 51,492 \\
3 &, 878 & 9,750 & 61,243 & & \\
4 &, 810 & 8,995 & 70,238 & & \\
5 &, 667 & 7,408 & 77,645 & & \\
6 &, 623 & 6,927 & 84,572 & & \\
7 &, 502 & 5,576 & 90,148 & & \\
8 &, 419 & 4,657 & 94,806 & & \\
9 &, 347 & 3,861 & 98,666 & & \\
\hline
\end{tabular}

Sumber : Hasil Analisis Data (2015). 
Tabel 7. Component Matrix

\begin{tabular}{lr}
\hline \multicolumn{1}{c}{ Perihal } & Component \\
\hline Tipe lahan yang dikerjakan & 1 \\
Keberlanjutan Usahatani &, 893 \\
Kemudahan Pemasaran Hasil &, 798 \\
Usia &, 794 \\
Konsistensi Sikap Berusahatani &, 767 \\
Kemudahan Memperoleh Saprodi &, 697 \\
Pendapatan yang diperoleh &, 671 \\
Tingkat Pendidikan &, 636 \\
Kemudahan Memperoleh Modal &, 593 \\
\hline
\end{tabular}

Extraction Method: Principal Component Analysis. ${ }^{a}$

a. 1 components extracted.

Nilai KMO and Bartlett's test adalah 0,855 dengan signifikansi 0,00 . Oleh karena nilai tersebut memiliki signifikansi jauh di bawah 0,05 , maka variabel dan sampel yang ada sebenarnya cukup dapat dianalisis lebih lanjut.

Communalities merupakan nilai yang menunjukkan kontribusi variabel tersebut terhadap faktor yang terbentuk, atau didefinisikan sebagai besaran nilai varians (dalam persentase) suatu variabel yang dapat dijelaskan oleh faktor yang terbentuk. Pada tabel di bawah, nilai communalities tinggi dalam mendeterminasi karakteristik sosial ekonomi petani peri urban adalah variabel "Tipe lahan yang dikerjakan (X15)" dengan nilai 79,7\%, "Keberlanjutan Usahatani (X17)" dengan nilai 63,7\%, "Kemudahan Pemasaran Hasil (X13)" dengan nilai $63,1 \%$ sedangkan variabel sisanya yang membentuk karakteristik sosial ekonomi petani peri urban. Semakin besar communalities sebuah variabel, berarti semakin erat hubungannya dengan faktor yang terbentuk.

Berdasarkan tabel di atas ada beberapa hal yang dapat diketahui :
- Nilai eigenvalues yang menunjukkan jumlah variabel yang menjadi anggota suatu faktor.

- Besaran variansi yang dapat dijelaskan oleh faktor dengan sejumlah variabel pembentuknya.

- Jumlah faktor yang dapat terbentuk oleh sejumlah variabel yang dimiliki

Setelah dilakukan ekstraksi, tampak dalam tabel di atas bahwa faktor yang terbentuk sebanyak 1 faktor, dengan masing-masing mempunyai nilai eigenvalues 4,634 sesuai dengan definisi eigenvalues, berarti kita dapat mengatakan bahwa faktor tersebut beranggotakan 4,634 variabel. Selain itu, tabel di atas menunjukkan adanya 9 component (variabel) yang dimasukkan dalam analisis faktor dengan masingmasing variabel memiliki variansi 1 , maka total variansi adalah $9 \times 1=9$. Sesuai dengan jumlah faktor yang terbentuk dan jumlah variansi masing-masing variabel yang diketahui, selanjutnya dapat dijelaskan oleh masing-masing faktor maupun oleh keseluruhan faktor yang terbentuk (baik sebelum dirotasi dan setelah dirotasi). 
Tabel Component Matrix di atas menunjukkan nilai loading factor masing-masing variabel terhadap faktor. Loading Factor adalah nilai yang menunjukkan hubungan (korelasi) suatu variabel terhadap faktor. Apabila suatu variabel mempunyai nilai loading factor terbesar pada faktor tertentu (dibanding faktor lainnya), maka variabel tersebut akan menjadi anggota atau pembentuk faktor tersebut. Nilai loading factor yang disarankan sebagai penentu komponen faktor yaitu setidaknya bernilai 0,7 (korelasi $\geq 0,7$ ). Sehingga dapat diketahui variabel penentu komponen faktor adalah "Usia (X1)", Tipe lahan yang dikerjakan (X15)", "Keberlanjutan Usahatani (X17)“, dan "Kemudahan Pemasaran Hasil (X13)".

\section{PEMBAHASAN \\ Keragaan (Performance) Sosial Ekonomi Petani Peri-Urban}

Para pelaku bidang pertanian Periurban di Kota Surabaya memiliki karakteristik yang tidak berbeda jauh dengan karakteristik petani di pedesaan, yaitu laki-laki berusia di atas 40 tahun, berpendidikan Sekolah Dasar, sudah berkeluarga dengan tanggungan anggota keluarga enam orang, mereka tercatat sebagai penduduk Kota Surabaya, yang merasa mendapat keuntungan dengan menjalankan kegiatan usaha tani, meskipun lahannya tergolong sempit $(<0.25-$ 50 ha) dengan tipe lahan tadah hujan.

Komoditi yang ditanam antara lain Kacang Panjang, Cabe, Sawi, Tomat dan Kangkung. Mereka menjual hasil taninya kepada tengkulak, meskipun mereka tergabung dalam kelompok tani. Untuk mendapatkan bibit dan sarana produksi pertanian, para petani menyatakan tidak mengalami kesulitan meskipun itu diperoleh dengan cara membeli dari Toko, KUD dan Kelompok Tani. Kesulitannya terletak kepada bagaimana mereka memperoleh modal, karena mereka kurang memiliki akses untuk memperoleh pinjaman modal, baik dari kelompok tani, maupun dari lembaga penyedia modal (koperasi atau Bank).

Kondisi sosial ekonomi serta lahan pertanian yang dikelola, melahirkan sikap para petani periurban yang merasa mendapatkan kendala berupa penerapan Perda Rencana Tata Ruang Wilayah Kota Surabaya. Sebagaimana permasalahan perkotaan pada umumnya, konversi lahan sangat sulit dihindari. Hal ini dikarenakan land-rent ratio di DKI Jakarta untuk lahan pertanian yang sangat rendah yaitu 1:500 untuk kawasan industri dan 1:622 untuk perumahan (Nasoetion dan Winoto, 1996).

Sikap pesimistis petani
periurban tidak terlihat dari pernyataan mereka yang masih akan tetap mempertahankan usaha taninya, dan berusaha untuk mewariskan usaha tani ini kepada anak-anaknya. Namun sikap ini tidak seiring dengan sikap konsistensinya terhadap usaha tani periurban. Dari hasil penelitian, diketahui bahwa seluruh responden (100\%) Petani Peri-Urban Kota Surabaya mengatakan "ya" terhadap keberlanjutan usahatani Peri-Urban. Pernyataan ini memiliki makna bahwa mereka yakin akan usahataninya dan masih akan melanjutkan usahataninya. Namun dari pernyataan sikap konsistensinya terhadap usahatani, hanya ada $18 \%$ petani yang bersikap konsisten.

Penelitian Husodo (2005) pada petani di Kota Yogyakarta juga 
telah menemukan bahwa semakin tinggi umur responden, luas lahan usahatani, beban ketergantungan, kontribusi pendapatan usahatani, pengalaman berusahatani dan alokasi waktu kerja non usahatani, semakin rendah kecenderungannya untuk memilih tetap berusahatani. Menurut Nugraha (2015), petani perkotaan di Surabaya memilki mekanisme survival atau strategi bertahan hidup. Strategi ini antara lain adalah dengan memperkerjakan istri dan anak di luar usahatani.

Sikap petani periurban Kota Surabaya terhadap pendapatan yang mereka terima, dinyatakan secara kualitatif berdasarkan persepsi masing-masing petani. Sebanyak $62 \%$ petani responden memaknai penghasilan dari usahatani ini cukup untuk makan dan biaya hidup seharihari, dan hanya $10 \%$ yang menyatakan bahwa penghasilan dari usahataninya kurang atau tidak mencukupi. Sikap ini dapat dikatakan sebagai salah satu bentuk hasil mekanisme survival yang dijalankan oleh petani periurban, yaitu melakukan penghematan atau mengencangkan sabuk (Nugraha, 2015).

\section{Faktor-Faktor Prinsipal yang Mempengaruhi Sosial Ekonomi Pertanian Periurban Kota Surabaya}

Dari hasil analisis faktor, diperoleh beberapa nilai loading faktor. Loading Factor adalah nilai yang menunjukkan hubungan (korelasi) suatu variabel terhadap faktor. Apabila suatu variabel mempunyai nilai loading factor terbesar pada faktor tertentu (dibanding faktor lainnya), maka variabel tersebut akan menjadi anggota atau pembentuk faktor tersebut. Nilai loading factor yang disarankan sebagai penentu komponen faktor yaitu setidaknya bernilai 0,7 (korelasi $\geq 0,7$ ). Sehingga dapat diketahui variabel penentu komponen faktor adalah Tipe lahan yang dikerjakan (X15)", "Keberlanjutan Usahatani (X17)", "Kemudahan Pemasaran Hasil (X13)", dan "Usia (X1)".

Tipe lahan yang dikerjakan petani periurban Kota Surabaya sebagian besar adalah lahan tadah hujan. Hal ini berkaitan dengan status keberadaan lahan tersebut. Lahan yang dipergunakan untuk usahatani merupakan lahan kosong diantara bangunan atau di bantaran sungai. Tipe lahan tadah hujan ini juga diketahui sebagai kendala dalam melakukan strategi bertahan hidup bagi petani periurban kota Surabaya (Nugraha, 2015). Untuk membuat lahan pertanian periurban yang memiliki irigasi teknis, bukanlah hal yang mudah. Salah satu alternatif yang dapat disarankan adalah pembuatan sumur. Jaminan

kepastian keberlanjutan usahatani merupakan salah satu faktor prinsip yang ditemukan dari hasil penelitian ini. Hasil ini sesuai dengan data dari Bappeko (2013) menyebutkan bahwa hampir di setiap wilayah yang menjadi obyek kegiatan pertanian perkotaan, mencapai kinerja yang cukup baik dimana hasil panen ratarata mencapai $70 \%$, sebanyak $95 \%$ responden mengaku pemkot perlu melanjutkan pertanian urban dan periurban dengan $36 \%$ beralasan untuk menambah penghasilan, $25 \%$ karena bermanfaat bagi masyarakat dan 25\% karena bisa konsumsi keluarga. Hanya sebanyak 5\% responden beralasan tidak perlu dilanjutkan karena tidak adanya lahan (Bappeko,2013). Penelitian Sampeliling dkk., (2012) juga menemukan bahwa status 
keberlanjutan pengembangan pertanian pada kondisi existing di DKI Jakarta, menunjukkan nilai indeks 48.7 atau kurang berkelanjutan.

Keberlanjutan usahatani juga perlu disertai dengan kemudahan pemasaran hasil pertanian periurban. Santoso dan Widya (2014), merumuskan strategi keberlanjutan gerakan pertanian perkotaan dengan analisa SWOT. Dari kajian ini, diperoleh hasil bahwa strategi utama yang perlu diterapkan adalah meningkatkan pendekatan kepada masyarakat untuk berpartisipasi dalam program Pertanian perkotaan, meningkatkan kualitas hasil panen melalui peningkatan sarana dan prasarana produksi, pelatihan dan intervensi teknologi serta mempertahankan dan meningkatkan gerakan pertanian perkotaan di Kota Surabaya.

Selanjutnya disebutkan
bahwa keberlanjutan gerakan
pertanian perkotaan di Surabaya
masih harus dipertahankan melalui
peningkatan pendekatan terhadap
keluarga miskin, meningkatkan
kualitas hasil panen melalui

peningkatan sarana dan prasarana produksi, pelatihan dan intervensi teknologi, dan memperluas jangkauan pemasaran hasil panen (Santoso dan Widya, 2014).

$$
\text { Selain permasalahan }
$$

semakin berkurangnya lahan

pertanian, terutama di daerah pinggiran perkotaan yang disebabkan oleh terjadinya konversi penggunaan lahan, permasalahan yang terjadi dalam keluarga petani juga dapat disebabkan oleh pengaruh struktur internal dalam keluarga itu sendiri, misalnya pengaruh sumberdaya keluarga, seperti ukuran dan komposisi (usia, jenis kelamin) anggota keluarga (White dalam Sitorus, 1992). Usia menjadi salah satu factor prinsip yang ditemukan pada penelitian ini. Usia responden hampir seluruhnya berada pada usia produktif yaitu $>30$ tahun. namun usia petani ini perlu diwaspadai manakala mereka tidak mewariskan usahataninya kepada anaknya. Hasil penelitian menunjukkan bahwa ada $14 \%$ responden yang tidak mewariskan usahatani kepada anaknya, dengan

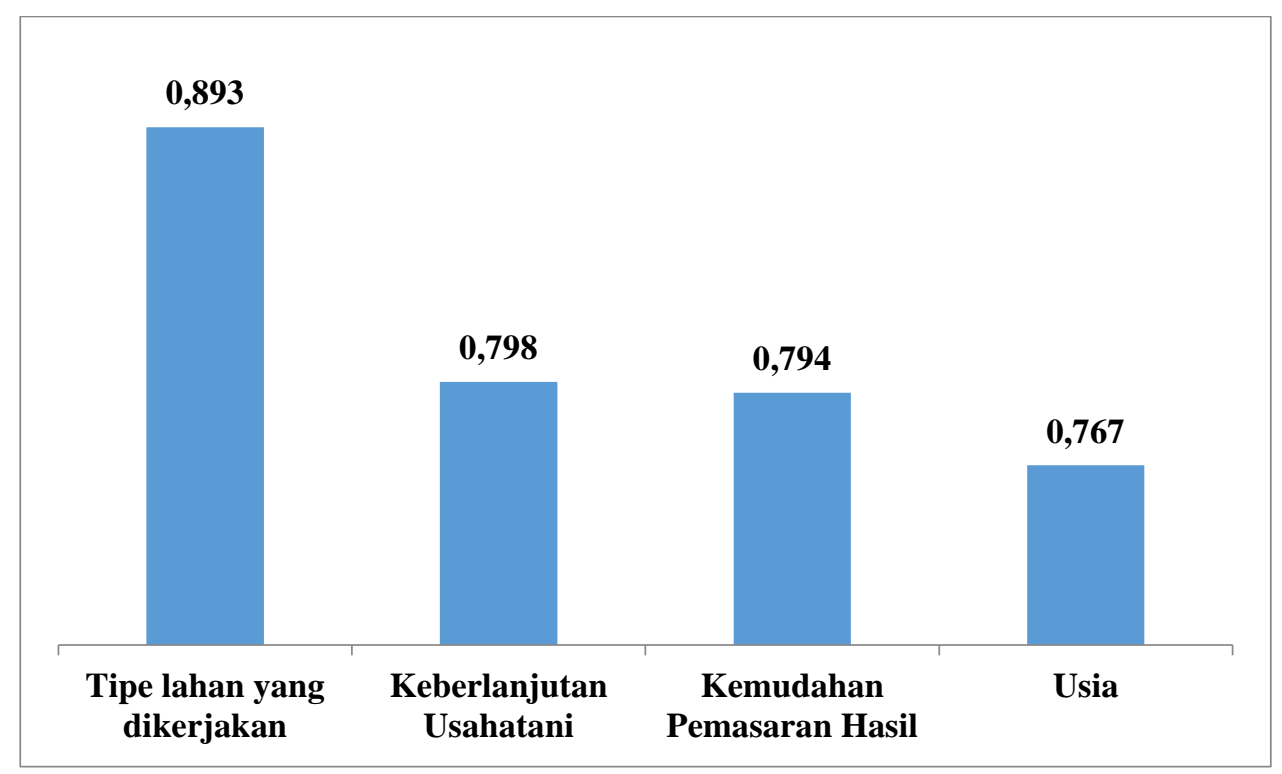

Gambar 20. Nilai loading faktor prinsip 
berbagai alasan. Alasan mereka antara lain bahwa anaknya diharapkan akan memperoleh kesempatan bekerja bidang lain, merasa kasihan kepada anaknya bila anaknya menjadi petani, dan lainnya menginginkan agar anaknya fokus untuk sekolah saja.

Apapun permasalahannya Haryono (2013) menyatakan bagaimanapun pengembangan pertanian perkotaan menjadi sangat penting, untuk: 1). Ketahanan pangan keluarga, 2). Sumber pendapatan 3). Kesempatan kerja, 4) Agrowidyawisata. Model Pertanian Perkotaan (Urban dan Periurban) harus hemat lahan, memperhatikan estetika, melalui proses produksi yang bersih dan ramah lingkungan, mengutamakan komoditas bernilai ekonomi dan berdaya saing, serta didukung inovasi teknologi maju.

\section{KESIMPULAN}

Dari hasil penelitian ini dapat diambil beberapa kesimpulan sebagai berikut :

Karakteristik petani periurban Kota Surabaya adalah sebagai berikut: didominasi laki-laki, penduduk Kota Surabaya, berusia di atas 40 tahun, berpendidikan Sekolah Dasar, sudah berkeluarga dengan tanggungan anggota keluarga enam orang. Luas lahan yang dikelola tergolong sempit (< 0.25 - 50 ha) dengan tipe lahan tadah hujan, dengan komoditi Kacang Panjang, Cabe, Sawi, Tomat dan Kangkung. Petani periurban menjual hasil taninya kepada tengkulak, meskipun mereka tergabung dalam kelompok tani. Bibit dan sarana produksi pertanian, diperoleh dengan cara membeli dari Toko, KUD dan Kelompok Tani. Modal usahatani merupakan modal sendiri. Kendala dalam usahatani yang dirasakan adalah penerapan Perda Rencana Tata Ruang Wilayah Kota Surabaya. Namun mereka akan tetap mempertahankan usaha taninya, dan berusaha untuk mewariskan usaha tani ini kepada anak-anaknya. Secara kualitatif berdasarkan persepsi, 62\% petani memaknai penghasilan dari usahatani ini sudah cukup untuk makan dan biaya hidup sehari-hari.

Terdapat empat komponen prinsipal sebagai penentu karakteristik sosial ekonomi petani periurban Kota Surabaya yaitu: Tipe lahan, Keberlanjutan Usahatani, Kemudahan Pemasaran Hasil, dan Usia.

\section{SARAN}

Mempertahankan dan mengembangkan pertanian periurban Kota Surabaya perlu dilakukan mengingat eksistensinya masih bermanfaat terutama sumber penghasilan petani periurban, serta sumbangannya terhadap keberadaan ruang terbuka hijau perkotaan. Bantuan dari Pemerintah Kota Surabaya diperlukan untuk pengadaan sumber air irigasi dan perluasan pemasaran hasil. 


\section{DAFTAR PUSTAKA}

Adiyoga W, Dimyati A, Soetiarso TA, Ameriana M. Suherman R., 2004. Persepsi Publik terhadap Keberadaan Pertanian Urban di Jakarta dan Bandung. J.Hort. 14(2):134-149.

Desrainy LMP, Fathimah IS, Hudalah D., 2010.

Karakterisitik Wilayah Periurban pada Metropolitan Jabodetabek. Regional and Rural Planning Research Group, School of Architecture, Planning and Policy Development, Institut Teknologi Bandung.

Ginting SW., 2010.Transformasi Spasial dan Diversifikasi Ekonomi pada Wilayah PeriUrban di Indonesia. Jurnal Arsitektur dan Perkotaan "KORIDOR" 1(1): 60-64

Haryono. 2013. Peran Nyata Hortikultura, Agronomi Dan

Pemuliaan Tanaman Terhadap Kontinyuitas Ketahanan Pangan Serta Pengembangan Pertanian Perkotaan Melalui Model Kawasan Rumah Pangan Lestari. Makalah Disampaikan pada Seminar Nasional 3 in One (Hortikultura, Agronomi dan Pemuliaan Tanaman) Universitas Brawijaya 21 Agustus 2013

Husodo S., 2005. Sikap Petani Terhadap Aktivitas Sektor Usahatani di Kawasan Peri Urban Yogyakarta. Jurnal IImu-IImu Pertanian 1 (1):3349.

Iriyani, D, Nugrahani P., 2013. Determinasi Perubahan
Kandungan Vitamin C, Klorofil Dan Karotenoid Beberapa Jenis Sayuran Daun Pada Pertanian Periurban Di Kota Surabaya. Laporan Penelitian Dosen Pemula, LPPM, Universitas Terbuka Tahun 2013.

Iriyani, D, Nugrahani P., Silvi P., 2014. Deteksi Kandungan Logam Pb Dan Residu Pestisida Beberapa Jenis Sayuran Daun Pada Pertanian Peri-Urban Kota Surabaya. Laporan Penelitian Lanjut Bidang Penelitian Keilmuan. LPPM, Universitas Terbuka Tahun 2014.

Kusumo RAB, Sunarti E, Pranadji DK. Analisis Peran Gender Serta Hubungannya Dengan Kesejahteraan Keluarga Petani Padi Dan Hortikultura Di Daerah Pinggiran Perkotaan. Media Gizi \& Keluarga, Desember 2008, 32 (2): 52-64 52

Mahfud MC, Sumarno, 1997. Paket Teknologi Komoditas Sayuran di Daerah Perkotaan. Apresiasi Teknologi Pertanian Perkotaan, 18 Oktober 1997 di IPPTP Denpasar 1-11.

Malhotra, N.K. dan Birks, D.F. 2007. Marketing Research: An Applied Approach, 3rd European Edition, Harlow, UK: Pearson Education.

Muhlisin, 2009. Daerah Periurban. Jurnal Dinamika Periurban 1:2-4.

Nazir, 2003. Metode Penelitian. Jakarta: PT. Ghalia Indonesia. 
Nugraha HS. 2015. Strategi

Bertahan Hidup Petani di Kelurahan Made Surabaya. Komunitas 4(3):1-10.

Purwanto SA., 2010. Bertani di Kota, Berumah di Desa: Studi Kasus Pertanian Kota di Jakarta Timur. Disertasi. Fakultas IImu Sosial dan IImu Politik. Program Studi Pascasarjana Departemen Antropologi. Universitas Indonesia. Jakarta.

Santoso EB, Widya, Rini Ratna. 2014. Gerakan Pertanian Perkotaan Dalam Mendukung Kemandirian Masyarakat Di Kota Surabaya. Seminar Nasional Cities 2014.

Sampeliling S, Sitorus SRP, Nurisyah S, Pramudya B. 2012. Kebijakan Pengembangan Pertanian Kota Berkelanjutan, Studi Kasus di DKI Jakarta.

Setyobudi, I. 2001. Menari di Antara Sawah dan Kota : Ambigius
Diri Petani-petani Terakhir di

Yogyakarta. Magelang:

Penerbit Indonesia Tera.

Suryadi A, Hardini D, Subagio $\mathrm{H}$, Nusantoro B., 2000. Pengkajian Skala Usahatani Komoditas Sayuran Di Wilayah Sekitar Perkotaan (Kasus Di Kabupaten Sidoarjo). Badan Pengkajian dan Pengembangan Teknologi Pertanian

Urbina, S. 2004. Essentials of Psychological Testing, New Jersey: John Wiley\&Sons.

Woodsworth, A. 2001. Urban Agriculture and Sustainable Cities. City Farmer, Canada's Office of Urban Agriculture. http://www.cityfarmer.org.

Yunus, H.S. 2001. Perubahan Pemanfaatan Lahan di Daerah Pinggiran Kota: Kasus di Pinggiran Kota Yogyakarta. PhD Thesis. Uppublished. Yogyakaarta: UGM. 